\title{
THE INFLUENGE OF CLOUDINESS ON THE NET RADIATION BALANCE OF A SNOW SURFACE WITH HIGH ALBEDO
}

\author{
By W. Амвасн \\ (Physikalisches Institut der Universität Innsbruck, Schöpfstrasse 4 I, 6o2o Innsbruck, Austria)
}

\begin{abstract}
The short-wave and long-wave radiant fluxes measured in the accumulation area of the Greenland ice sheet during a mid-summer period are discussed with respect to their dependence on cloudiness. At a cloudiness of $\mathrm{IO} / \mathrm{IO}$, a mean value of $270 \mathrm{~J} / \mathrm{cm}^{2} \mathrm{~d}$ is obtained for the daily totals of net radiation balance, whereas a mean value of only $75 \mathrm{~J} / \mathrm{cm}^{2} \mathrm{~d}$ is observed at $\mathrm{o} / \mathrm{I} 0$. The energy excess of the net radiation balance with overcast sky is due to the significant influence of the incoming long-wave radiation and the high albedo of the surface (average of $84 \%$ ). High values of net radiation balance are therefore correlated with high values of long-wave radiation balance and low values of short-wave radiation balance.

RÉsumé. L'influence de la nebulosité sur le bilan radiatif net d'une surface de neige à fort albedo. Le flux de rayonnement en ondes courtes et longues, mesuré dans la zone d'accumulation de la calotte glaciaire du Groënland pendant une demi-période estivale est discuté dans sa dépendance par rapport à la nébulosité. Par une couverture nuageuse de $10 / 10$ on obtient une valeur moyenne de $270 \mathrm{~J} / \mathrm{cm}^{2} \mathrm{~d}$ pour le total journalier du bilan radiatif net, alors qu'on observe une valeur moyenne de seulement $75 \mathrm{~J} / \mathrm{cm}^{2} \mathrm{~d}$ à o/ 1 o de nébulosité. L'excédent énergétique du bilan radiatif net sous ciel couvert est dû à l'influence significative du rayonnement incident de grande longueur d'onde et au fort albédo de la surface (en moyenne $84 \%$ ). Les valeurs élevées du bilan radiatif net sont donc liées aux fortes valeurs du bilan radiatif de grande longueur d'onde et aux faibles valeurs du bilan de rayonnement de courtes longueurs d'onde.
\end{abstract}

Zusammenfassung. Der Einfluss von Bewölkung auf die Gesamtstrahl'ıngsbilanz einer Schneefläche mit hoher Albedo. Die kurzwelligen und langwelligen Strahlungsströme werden für eine Station im Akkumulationsgebiet des Grönländischen Inlandeises für eine hochsommerliche Periode in ihrer gegenseitigen Abhängigkeit und ihrer Abhängigkeit von der Bewölkung diskutiert. Bei ro/1o Bewölkung erhält man als Mittelwert für die Tagessummen der Gesamtstrahlungsbilanz $270 \mathrm{~J} / \mathrm{cm}^{2} \mathrm{~d}$ während bei o/ Io Bewölkung nur $75 \mathrm{~J} / \mathrm{cm}^{2} \mathrm{~d}$ resultieren. Der grössere Energiegewinn durch Strahlung bei bedecktem Himmel ist in dem signifikanten Einfluss der langwelligen Einstrahlung und der hohen Albedo (Mittel 84\%) begründet. Grosse Werte der Gesamtstrahlungsbilanz sind daher mit hohen Werten der langwelligen Strahlungsbilanz und geringen Werten der kurzwelligen Strahlungsbilanz korreliert.

\section{INTRODUCTION}

Results of radiation balance measurements in the accumulation area of the Greenland ice sheet (station Carrefour, I $850 \mathrm{~m}$ a.s.1., lat. $69^{\circ} 49^{\prime} 25^{\prime \prime}$ N., long. $47^{\circ} 25^{\prime} 57^{\prime \prime}$ W., EGIG II-I 967 ), made between ${ }_{3} 3$ May and 28 July 1967 , are discussed from the viewpoint of a paradox which may be formulated as follows: The daily totals of the net radiation balance of a snow surface with high albedo increase with increasing cloudiness. This is also valid for midsummer periods, when the extraterrestrial incoming short-wave radiation is extremely high. The core of the paradox lies in the accentuation of the validity of this statement during mid-summer periods. If it were restricted to periods with low solar elevation it would be a triviality.

An analysis of the short-wave and long-wave radiation balance as dependent on the cloudiness makes the paradox understandable. Cloudiness decreases the short-wave radiation balance and increases long-wave radiation balance, which means that it has opposite effect in the two spectral ranges. From the results of measurements it follows that the influence of longwave radiation balance prevails. Figure $\mathrm{I}$ gives a schematic drawing of radiant fluxes, the indices $0 / 10$ and ro/ ro being the degree of cloudiness. It shows that the incoming short-wave radiation $G$, the reflected short-wave radiation $R$, the incoming long-wave radiation $A$, and the outgoing long-wave radiation $E$, vary with cloudiness in the following manner:

$$
\begin{array}{ll}
G(\mathrm{ro} / \mathrm{I0})<G(\mathrm{o} / \mathrm{ro}), & A(\mathrm{ro} / \mathrm{Io})>A(\mathrm{o} / \mathrm{ro}), \\
R(\mathrm{ro} / \mathrm{Io})<R(\mathrm{o} / \mathrm{ro}), & E(\mathrm{ro} / \mathrm{Io}) \approx E(\mathrm{o} / \mathrm{ro}) .
\end{array}
$$



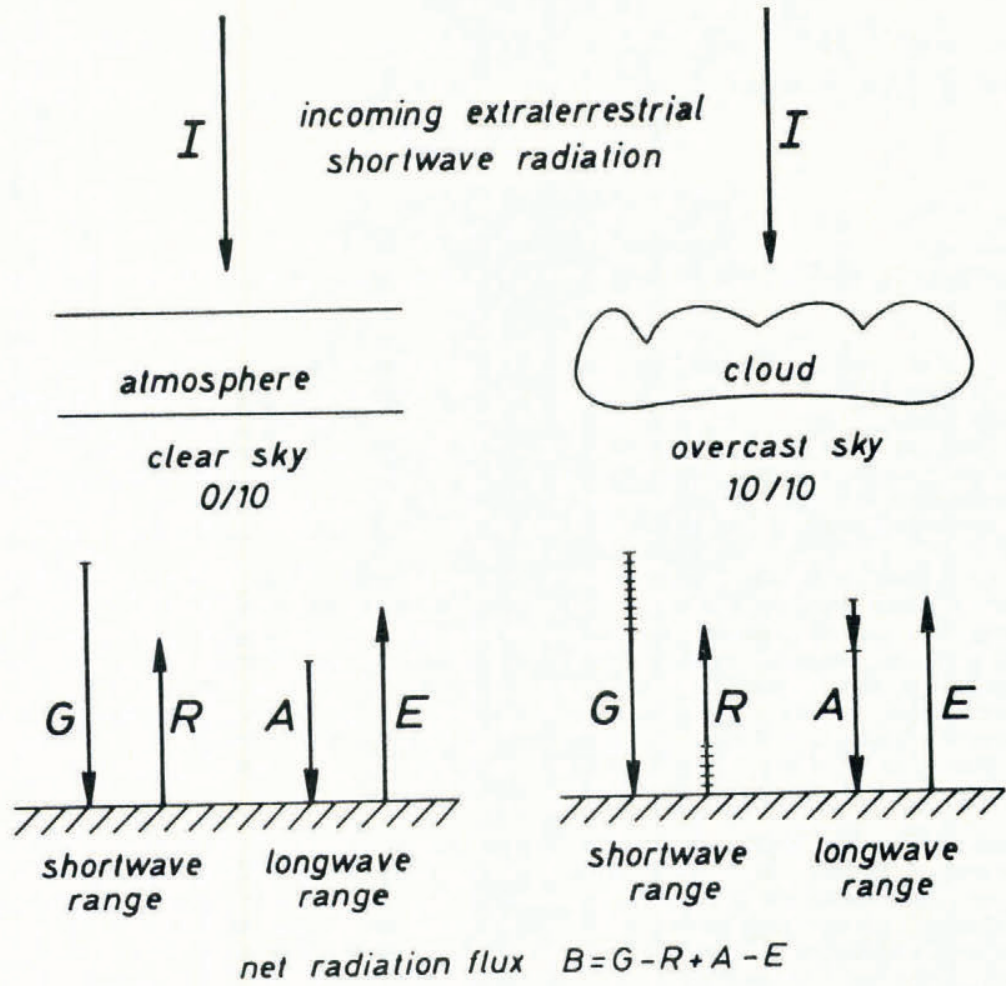

Fig. I. Schematic drawing of the radiant fluxes with clear and overcast sky.

The mean values for the daily totals of the net radiation balance $B$ obtained for a mean albedo of $84 \%$ at Station Carrefour, are the following:*

$$
\begin{aligned}
& \text { daily totals at o/ } 10 \text { cloudiness: } 18 \mathrm{cal} / \mathrm{cm}^{2} \mathrm{~d} \\
& \text { daily totals at ro/ } 10 \text { cloudiness: } 65 \mathrm{cal} / \mathrm{cm}^{2} \mathrm{~d}
\end{aligned}
$$

The radiation balance of polar snow and ice surfaces has already been studied in detail by several authors, above all by Holmgren (1971) and Hoinkes (1970). Holmgren (1971), for example found out that the radiation balance of frozen snow surfaces (Devon Ice Cap) in mid-summer is $+40 \mathrm{cal} / \mathrm{cm}^{2} \mathrm{~d}$ with dense cloudiness, and $+20 \mathrm{cal} / \mathrm{cm}^{2} \mathrm{~d}$ with a clear sky. Hoinkes (1970) mentioned that the net radiation balance is decisively influenced by long-wave radiation balance, the influence of cloudiness thus being evident (based on data from "Little America V", Antarctica). In the Alps at 3000 m a.s.l., Sauberer and Dirmhirn (1952), with an albedo of $80 \%$, obtained a net radiation balance of $-25 \mathrm{cal} / \mathrm{cm}^{2} \mathrm{~d}$ at $\mathrm{o} / \mathrm{Io}$ cloudiness and $+69 \mathrm{cal} / \mathrm{cm}^{2} \mathrm{~d}$ at $10 /$ ro. Further studies on the radiation balance of snow and ice surfaces have been reviewed and discussed by Hoinkes ([c $\left.\left.{ }^{\mathrm{I}}{ }_{964}{ }^{6}\right]\right)$.

\section{SHORT-WAVE RADIANT FLUX AND GLOUDINESS}

Figure 2 shows the ratio between the daily totals of incoming short-wave radiation $G$ and extraterrestrial radiation $I$ on a horizontal surface as a function of time. The ratio varies

* SI-units: $1 \mathrm{cal} / \mathrm{cm}^{2} \mathrm{~d}=0.484 \mathrm{~W} / \mathrm{m}^{2} ; \mathrm{r} \mathrm{cal} / \mathrm{cm}^{2} \mathrm{~h}=11.63 \mathrm{~W} / \mathrm{m}^{2}$. 


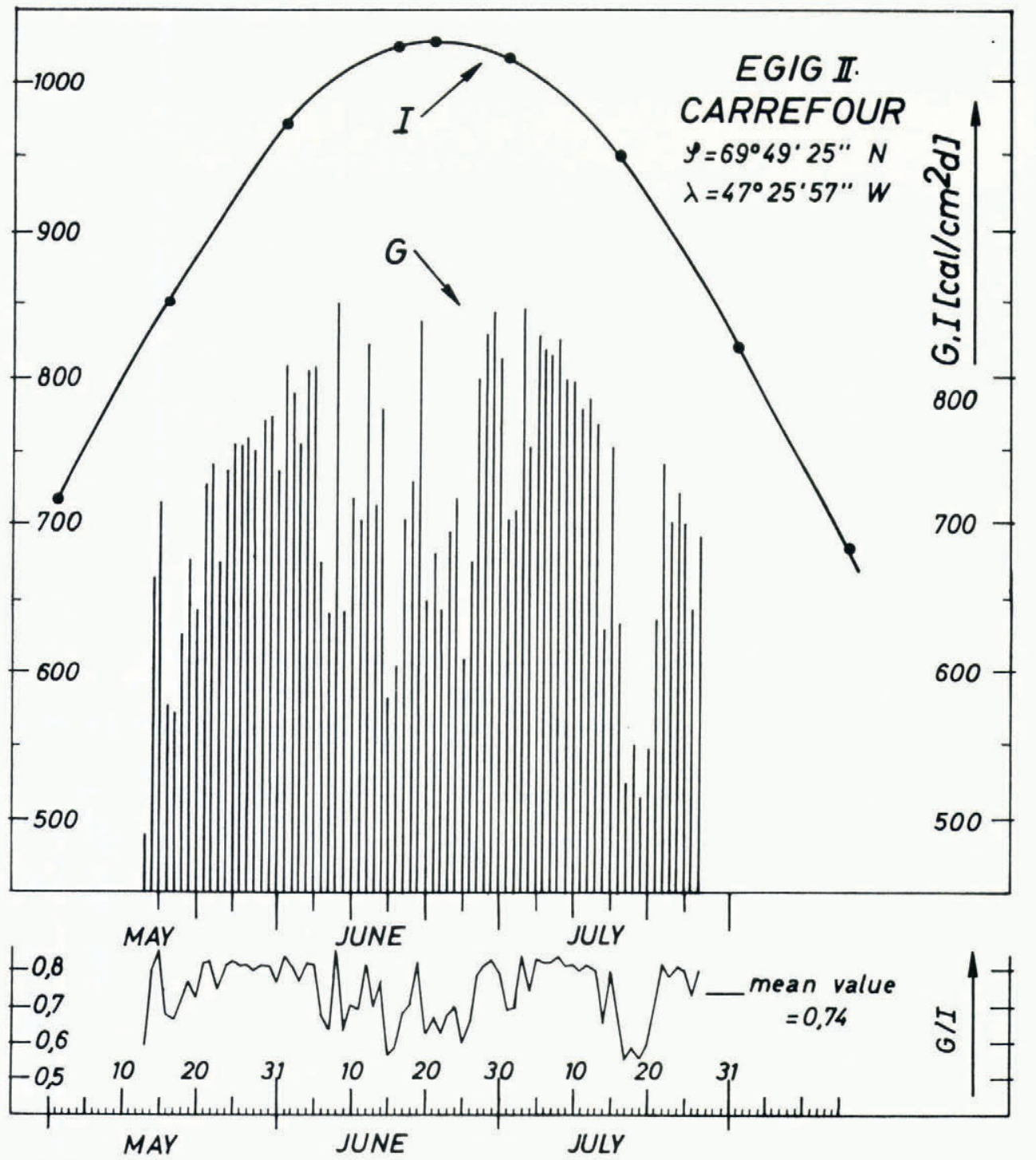

Fig. 2. Daily totals of extraterrestrial radiation on a horizontal surface $I$ and of incoming short-wave radiation $G$ as dependent on time. The ratio $G / I$ is plotted in the lower part of the diagram, the resulting mean value is 0.74 .

between 0.56 and 0.85 , having a mean value of 0.74 . These variations are due to differences in cloudiness (Fig. 3). At Io/10, they are large because of the different opacity of clouds. The period of measurement is approximately symmetrical to 2 I June (Fig. 2), showing extremely high values of extraterrestrial radiation.

\section{LONG-WAVE RADIATION BALANGE AND GLOUDINESS}

Figure 4 confirms the relation between long-wave radiation balance and cloudiness which has been found over snow and ice surfaces already by several authors: The long-wave radiation balance shows strongly negative values at a cloudiness of $\mathrm{o} / \mathrm{ro}$ and slightly negative 


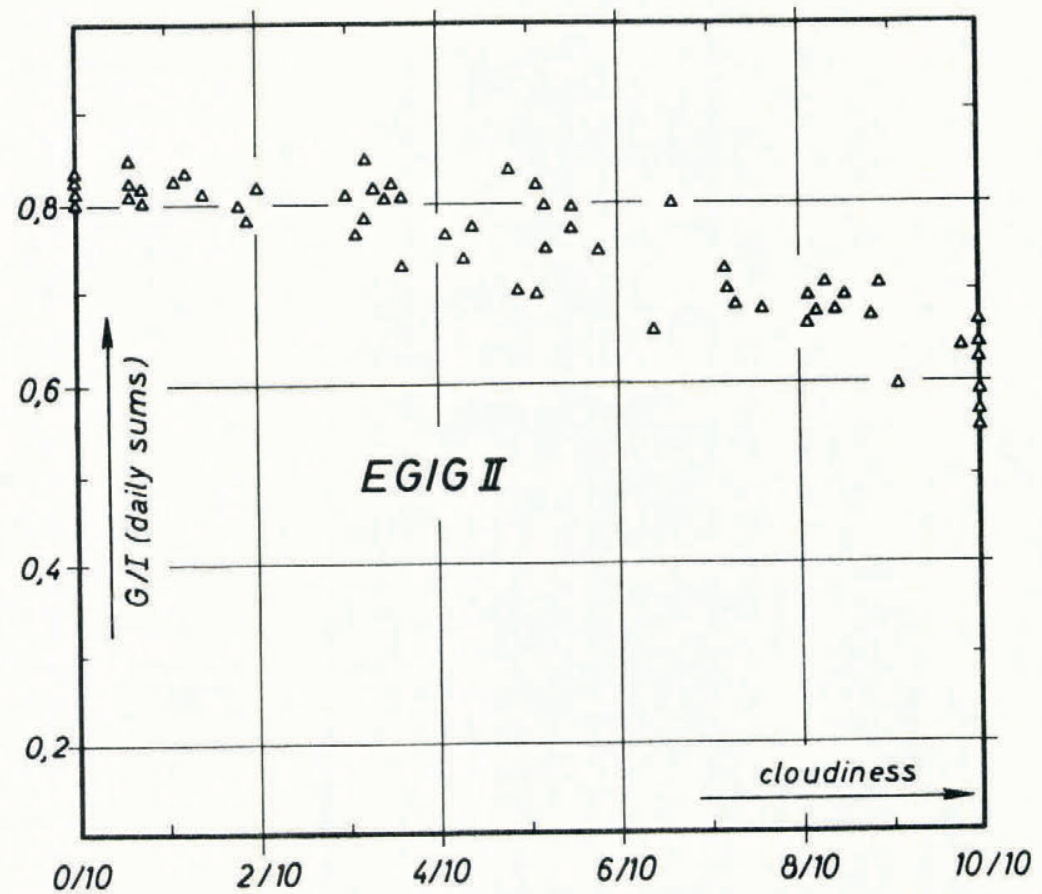

Fig. 3. The ratio $G / I(G=$ incoming short-wave radiation, $I=$ extraterrestrial radiation $)$ as a function of cloudiness.

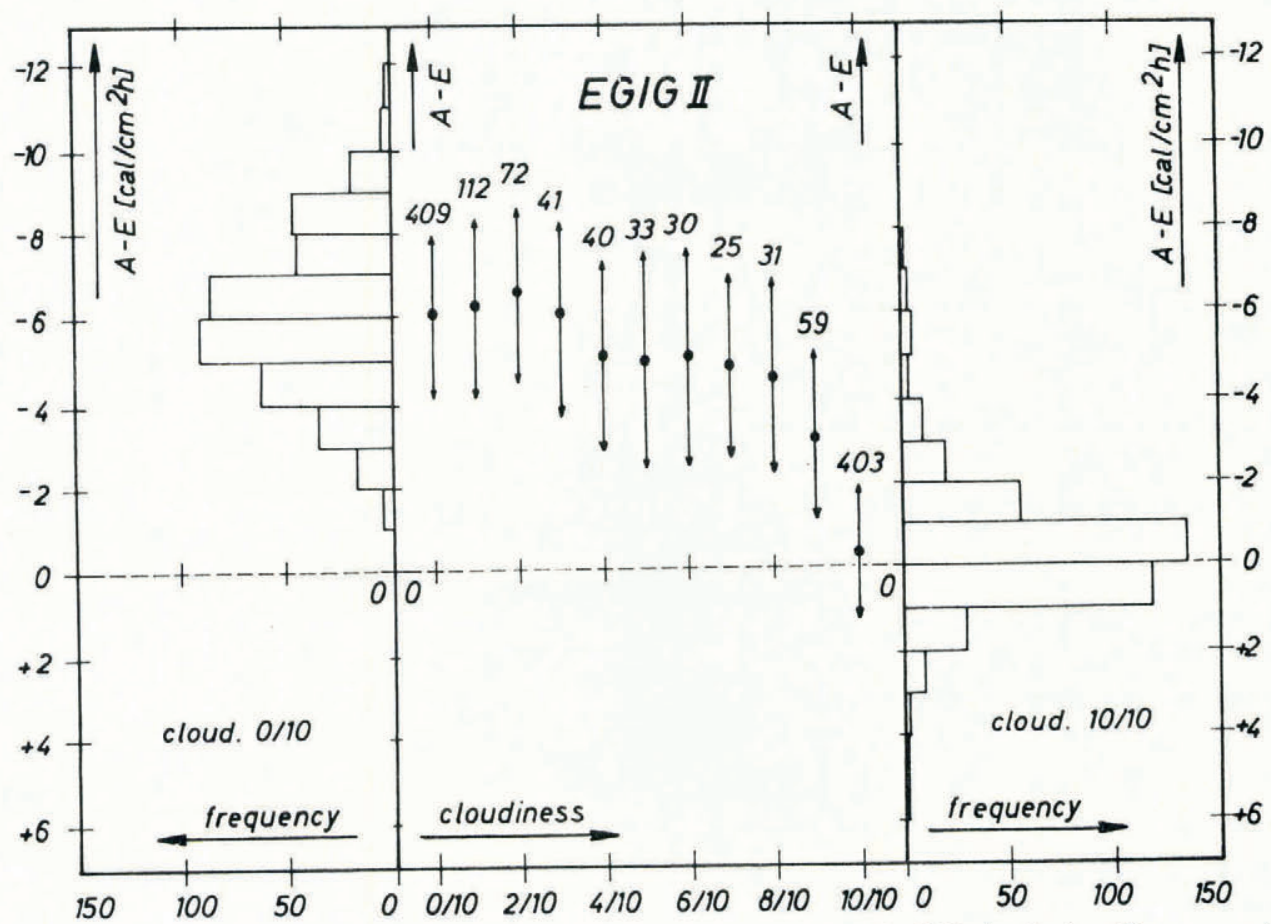

Fig. 4. The long-wave radiation balance $A-E$ as a function of cloudiness ( 1247 individual values). The arrows give the standard deviation, figures indicate numbers of samples for each group of cloudiness, the frequency distribution at o/ 10 and Io/ Io cloudiness are given in the left part and right part of the diagram. 
values at $10 / 10$, the relation being interpreted better in terms of a quadratic law than a linear one. Hourly estimates of cloudiness and hourly totals of long-wave radiation balance were used for the evaluation, comprising I 247 individual observations.

\section{RADiATion BALANGE AND CLOUDiness}

Figure 5 shows the daily totals of radiant fluxes for two series of measurements over snow surfaces with high albedo (EGIG I, EGIG II); for the EGIG I series (Camp IV-EGIG I959,

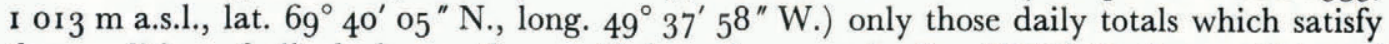
the condition of albedo larger than $70 \%$ have been used. For EGIG II, the condition of albedo larger than $70 \%$ was satisfied throughout the whole series. The mean value of the albedo was $84 \%$, a value which has been stated for dry snow surfaces of polar regions also by other authors.

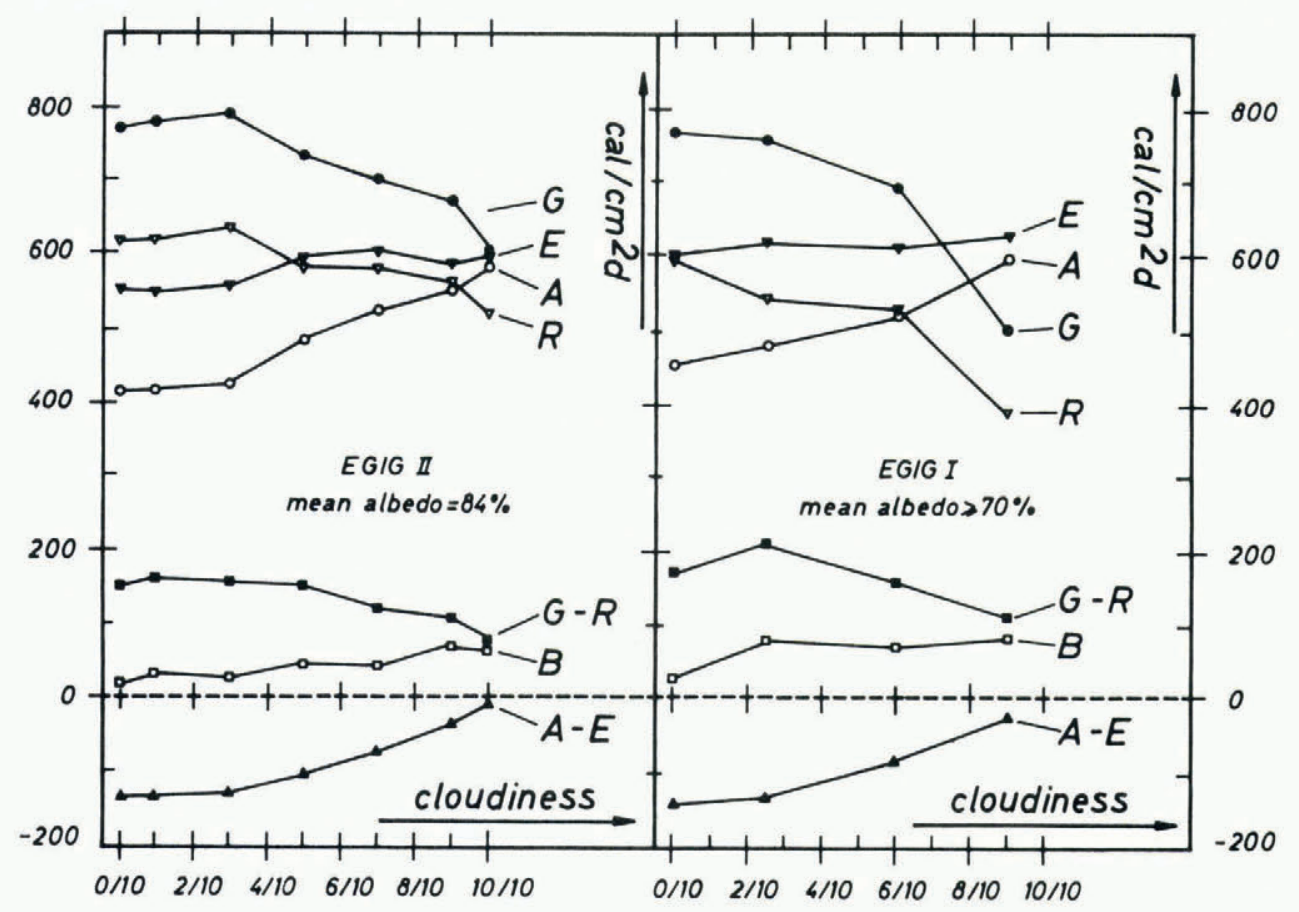

Fig. 5. Daily totals of the ratiant fluxes as dependent on the cloudiness for two series of measurements (EGIG I and EGIG II). For groups of cloudiness see Table $I$.

The paradox is evident in Figure 5: The increase in the net radiation balance from minimum cloudiness toward maximum cloudiness, amounts in the case of EGIG I from $27 \mathrm{cal} /$ $\mathrm{cm}^{2} \mathrm{~d}$ to $83 \mathrm{cal} / \mathrm{cm}^{2} \mathrm{~d}$ and in the case of EGIG II from $18 \mathrm{cal} / \mathrm{cm}^{2} \mathrm{~d}$ to $65 \mathrm{cal} / \mathrm{cm}^{2} \mathrm{~d}$. In order to get a sufficient number of cases for the various groups of cloudiness, the classification of Table I was used. The increase in net radiation balance with cloudiness becomes better understandable when comparing the respective dependence of short-wave and long-wave radiation balances on cloudiness. The increase in the long-wave balance $A-E$ with increasing cloudiness is greater than the corresponding decrease of short-wave balance $G-R$. 
Table I. Groups of cloudiness in the EGIG I AND EGIG II series

Groups of cloudiness $c$ in the series of EGIG I: Estimation of cloudiness in tenths, three times a day

$$
\begin{array}{ccccc}
\qquad 0 \leqslant c \leqslant 5.1 ; & 1.5<c \leqslant 4.5 ; & 4.5<c \leqslant 8.5 ; & 8.5<c \leqslant 10 \\
\text { Number of samples } & 3 & 3 & 3 & 8
\end{array}
$$

Groups of cloudiness $c$ in the series of EGIG II : Hourly estimations of cloudiness in tenths

$\begin{array}{rcccccc}0 ; & 0<c \leqslant 2 ; & 2<c \leqslant 4 ; & 4<c \leqslant 6 ; & 6<c \leqslant 8 ; & 8<c<\text { 10; } & \text { 10 } \\ \text { Number of samples I3 } & \text { I2 } & 7 & \text { I I } & 4 & 9 & 9\end{array}$

\section{Hourly VARIATIONS OF RADIANT FLUXES AS DEPENDENT ON CLOUDINESS}

Figure 6 gives the hourly variations of the radiant fluxes for a cloudiness of $0 / 10$ and $10 / 10$ and an albedo larger than $70 \%$. Although the amplitude of the hourly variation of net radiation at $\mathrm{o} / \mathrm{IO}$ is larger than at Io/10, at a cloudiness of o/10 the daily total, represented as the area below the curve of $B$ is composed of almost equal negative and positive parts. At a cloudiness of $10 / 10$, however, only the positive part of net radiation balance will be important, as negative values of $B$ are negligible.
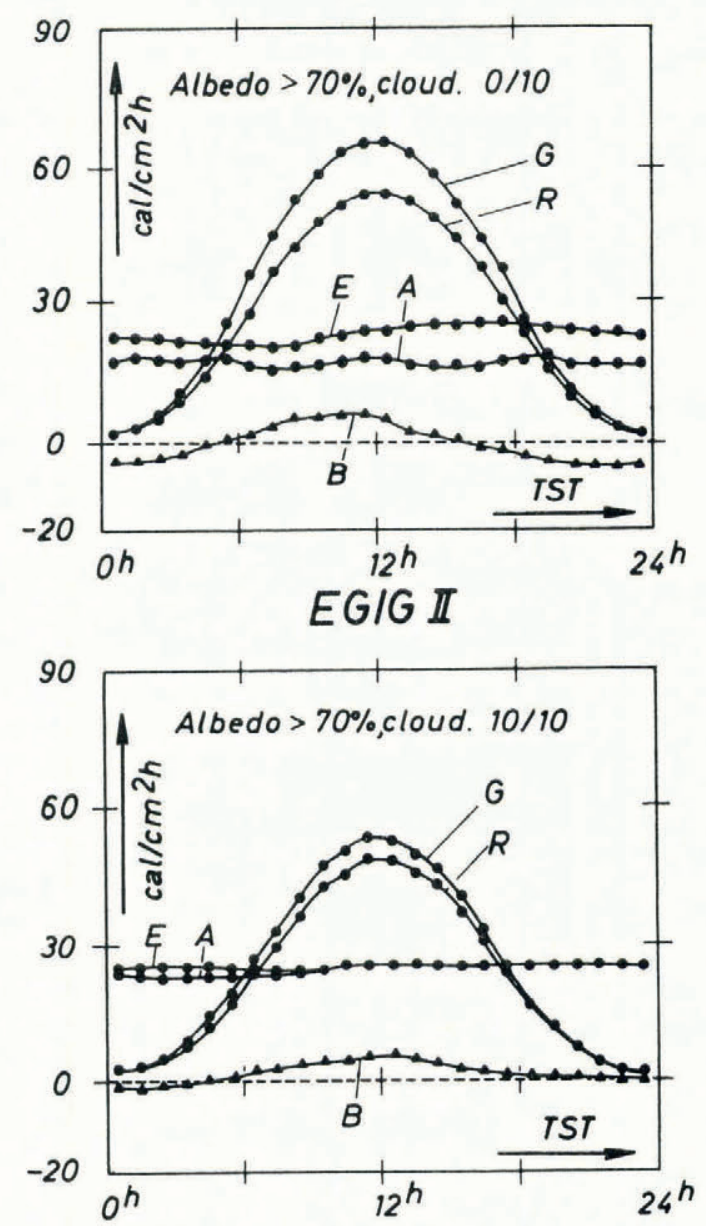

Fig. 6. Mean hourly variations of the radiant fluxes $G, R, A, E$ and $B$ for a cloudiness of o/ $r o$ and $r o / 10$. 


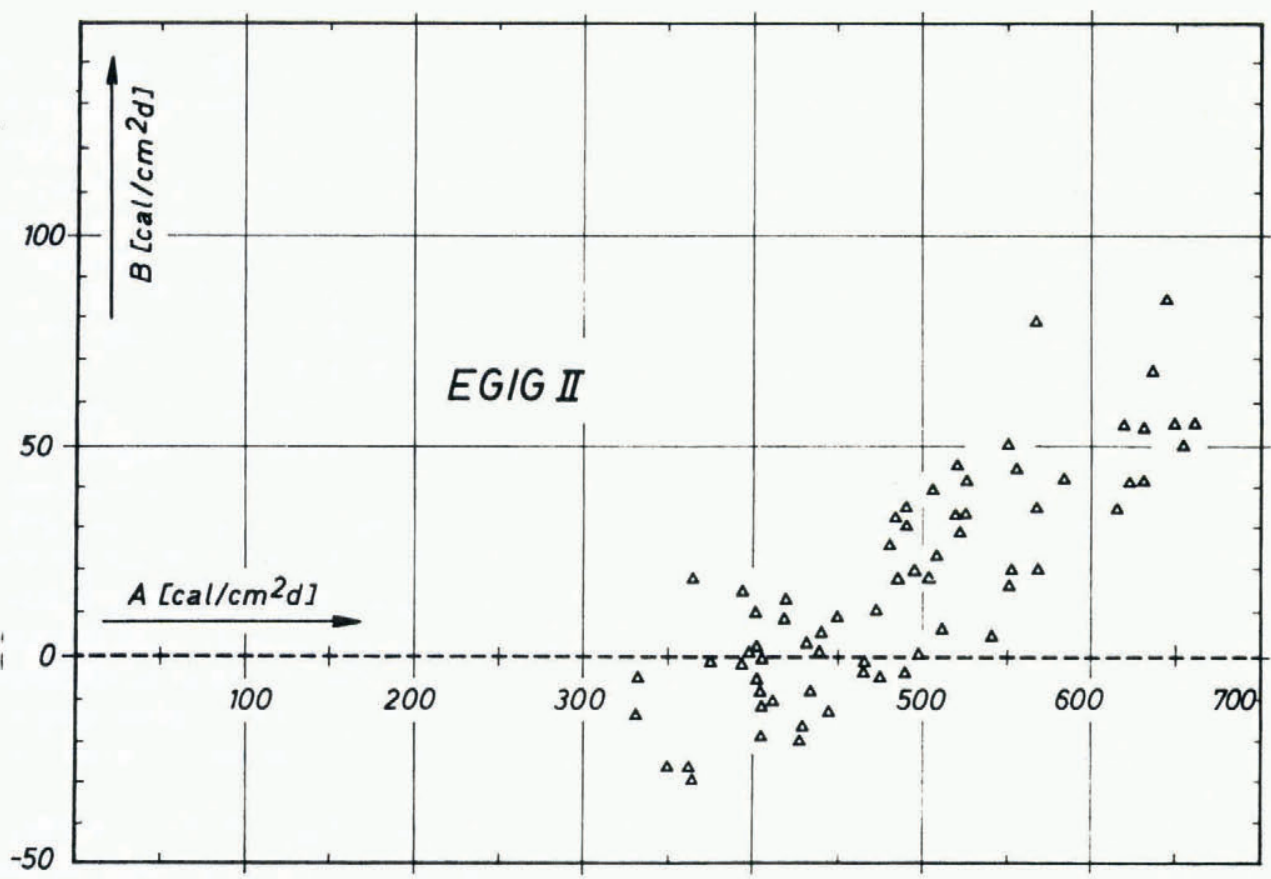

Fig. 7. Relation between the incoming long-wave radiation $A$ and the net radiation balance $B$.

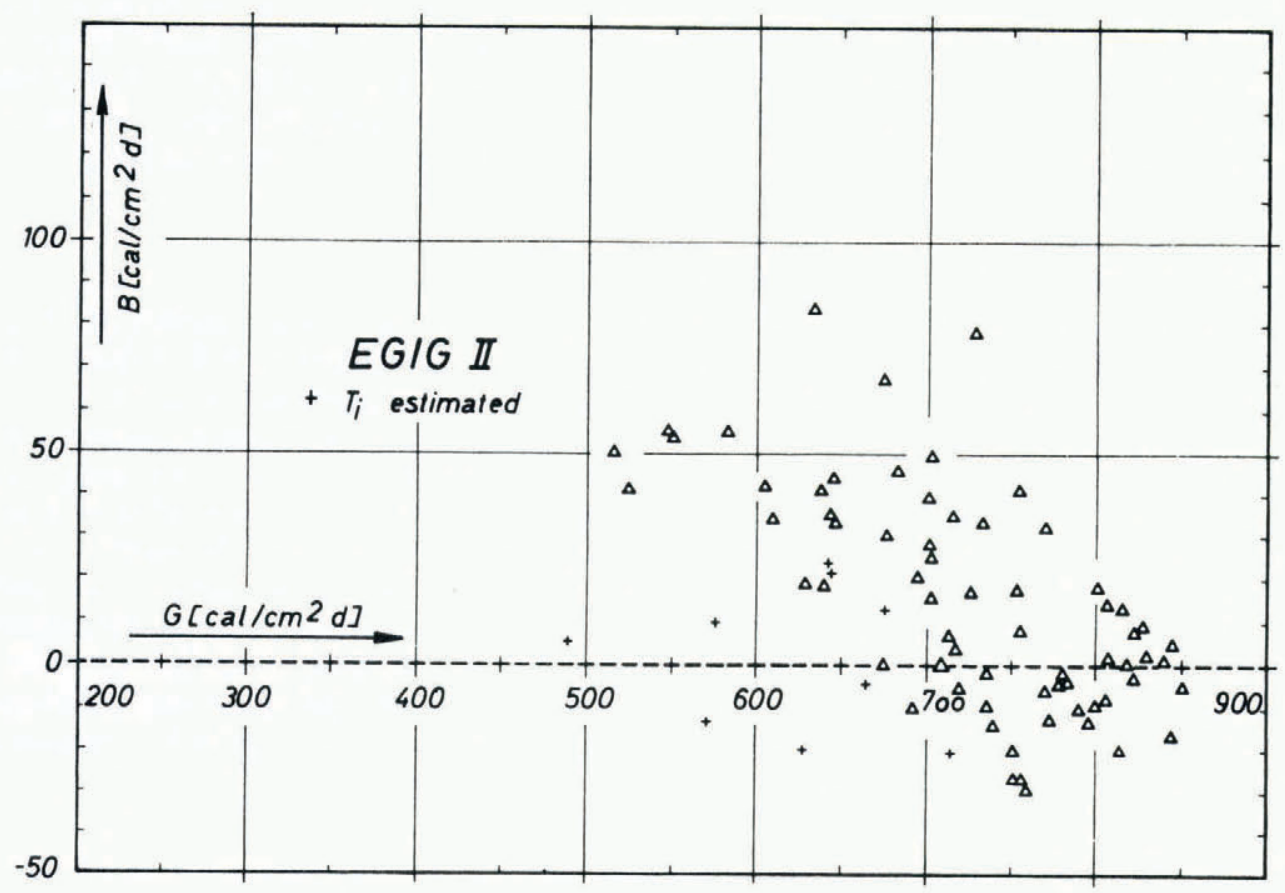

Fig. 8. Relation between the incoming short-wave radiation $G$ and the net radiation balance $B$. 


\section{RELATIONS BETWEEN THE RADIANT FLUXES (DAILY TOTALS)}

Hoinkes (1970) has already pointed out that the radiation balance at high albedo values is governed mainly by long-wave radiant fluxes. Figure 7 proves that the incoming long-wave radiant flux $A$ is in positive correlation with the net radiation balance $B$. The range of values coincides also quantitatively with the range given by Hoinkes (1970) whose data, measured during the early Antarctic summer (September 1957 to January 1958), also show very well the range of negative values of net radiation balance. The incoming short-wave radiation $G$, however, is in a weak negative correlation to the net radiation balance $B$ (Fig. 8). The fact that the present series of measurements is nearly symmetrical with respect to the solstice ( 13 May to 28 July) means that the change in extraterrestrial radiant flux is small.

The relations between the net radiation balance $B$ and the short-wave and long-wave balances are shown for individual months in Figure 9. Owing to the separate treatment of the individual months, changes of extraterrestrial radiant flux are of minor importance. Again, long-wave radiation balance $A-E$ is in good positive correlation to the net radiation balance $B$; the short-wave radiation balance $G-R$, however, shows only weak negative correlation to the net radiation balance $B$. The relation between the short-wave radiation balance $G-R$ and the long-wave radiation balance $A-E$ in Figure 10 is still clearer. The paradox mentioned above is expressed numerically as follows: A decrease of the short-wave radiation balance $G-R$ by $100 \mathrm{cal} / \mathrm{cm}^{2} \mathrm{~d}$ (owing to increased cloudiness) is related to an increase of the long-wave radiation balance $A-E$ by approximately $150 \mathrm{cal} / \mathrm{cm}^{2} \mathrm{~d}$. This relation is applicable to each individual month.

Hence the quantitive explanation of the paradox follows: at a high albedo, a decrease (owing to greater cloudiness) in the short-wave radiation balance $G-R$ even in mid-summer is more than compensated for by an increase in the long-wave radiation balance $A-E$. The energy gain owing to radiation is about $50 \mathrm{cal} / \mathrm{cm}^{2} \mathrm{~d}$ higher when the sky is overcast than when cloudless, although maximum values of the incoming short-wave radiation of more than $800 \mathrm{cal} / \mathrm{cm}^{2} \mathrm{~d}$ occur in this period. On the basis of the measured radiant fluxes, it can be estimated that the effect under discussion occurs at an albedo larger than $75 \%$. This means that large areas of the polar ice sheets fulfill the condition for this paradoxical effect. For hourly totals of net radiation balance, however, the paradox cannot in general be established.

\section{INSTRUMENTATION, CALIBRATION AND EVALUATION}

Instrumentation, calibration and evaluation followed a method described earlier (Ambach, 1963). Two solarimeters (Moll-Gorczynski) and a Lupolene instrument by R. Schulze were used as radiation detectors. Calibration in the short-wave range was made in the field using direct solar radiation at levelled detector surfaces by means of a Linke-Feussner actinometer. The temperature coefficient of the instruments was applied. Calibration in the long-wave range was made in the laboratory following a previously described method (Ambach and others, 1963). For the evaluation, the difference in the sensitivities of the thermopiles of the Lupolene instrument to short-wave radiation and long-wave radiation was taken into account.

The results of calibration in the short-wave range confirm the dependence of the calibration factor on solar elevation as observed in earlier studies. Because of an azimuth effect, there are slight differences in the calibration factor for series measured before noon and after noon (Fig. II). The calibration factor for isotropic radiation $f_{\mathrm{i}}$ was calculated according to the formula given by Liljequist (1956)

$$
\frac{\mathrm{I}}{f_{1}}=\int_{0}^{\pi / 2} \frac{\sin 2 h}{f(h)} \mathrm{d} h,
$$



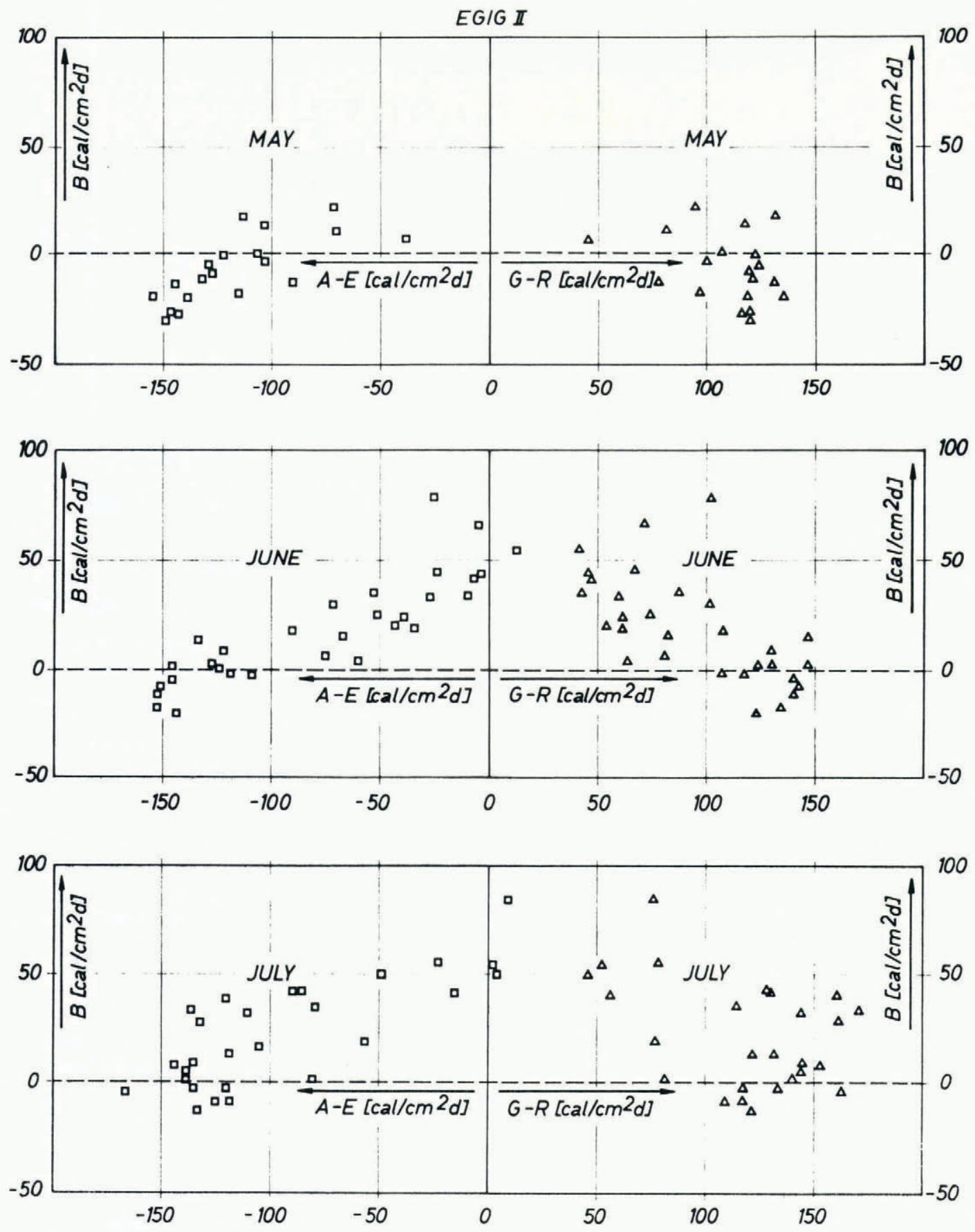

Fig. 9. Relation between the net radiation balance $B$ and the long-wave radiation balance $A-E$, as well as short-wave radiation balance $G-R$. 


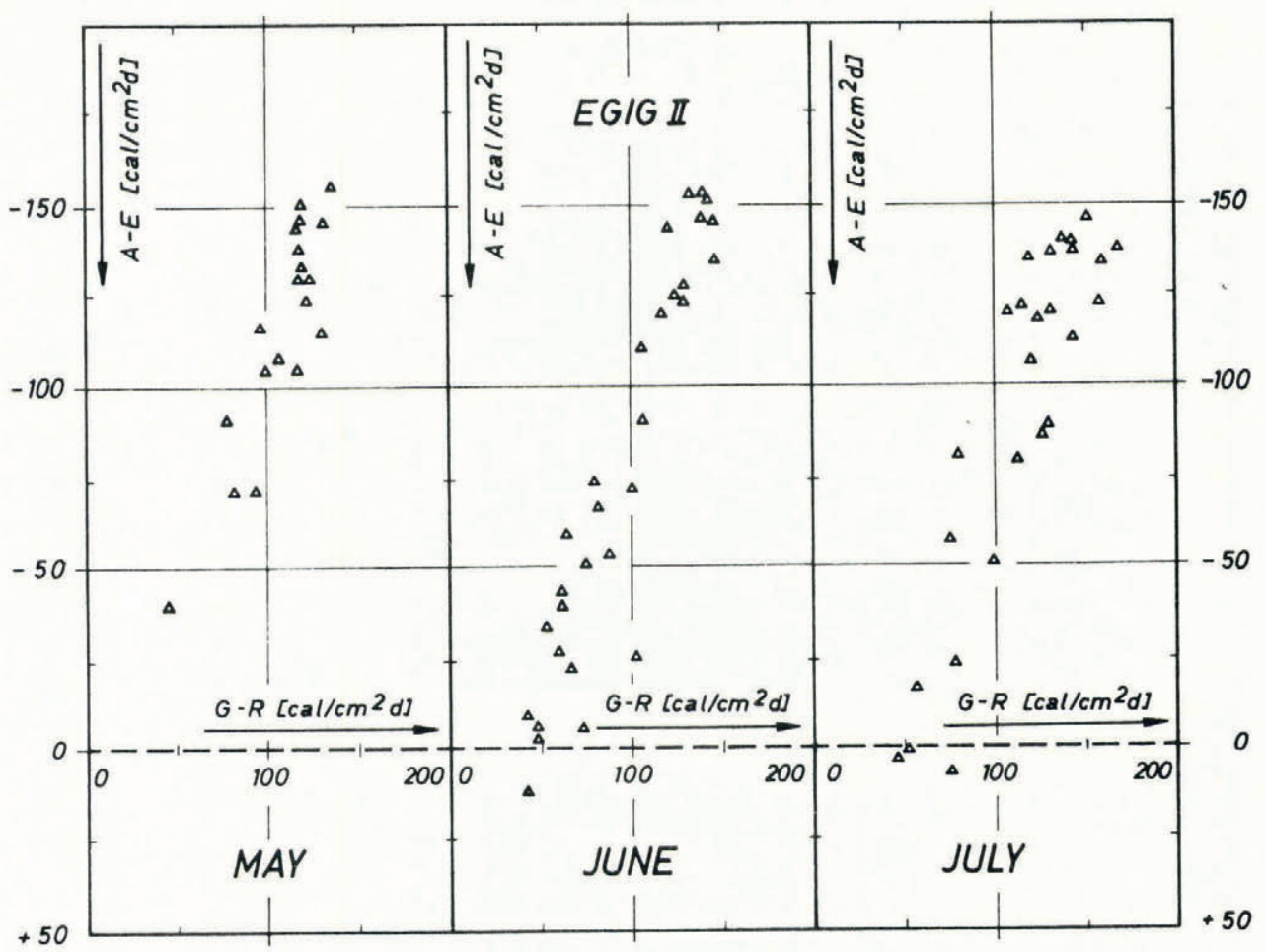

Fig. Io. Relation between the short-wave radiation balance $G-R$ and the long-wave radiation balance $A-E$.

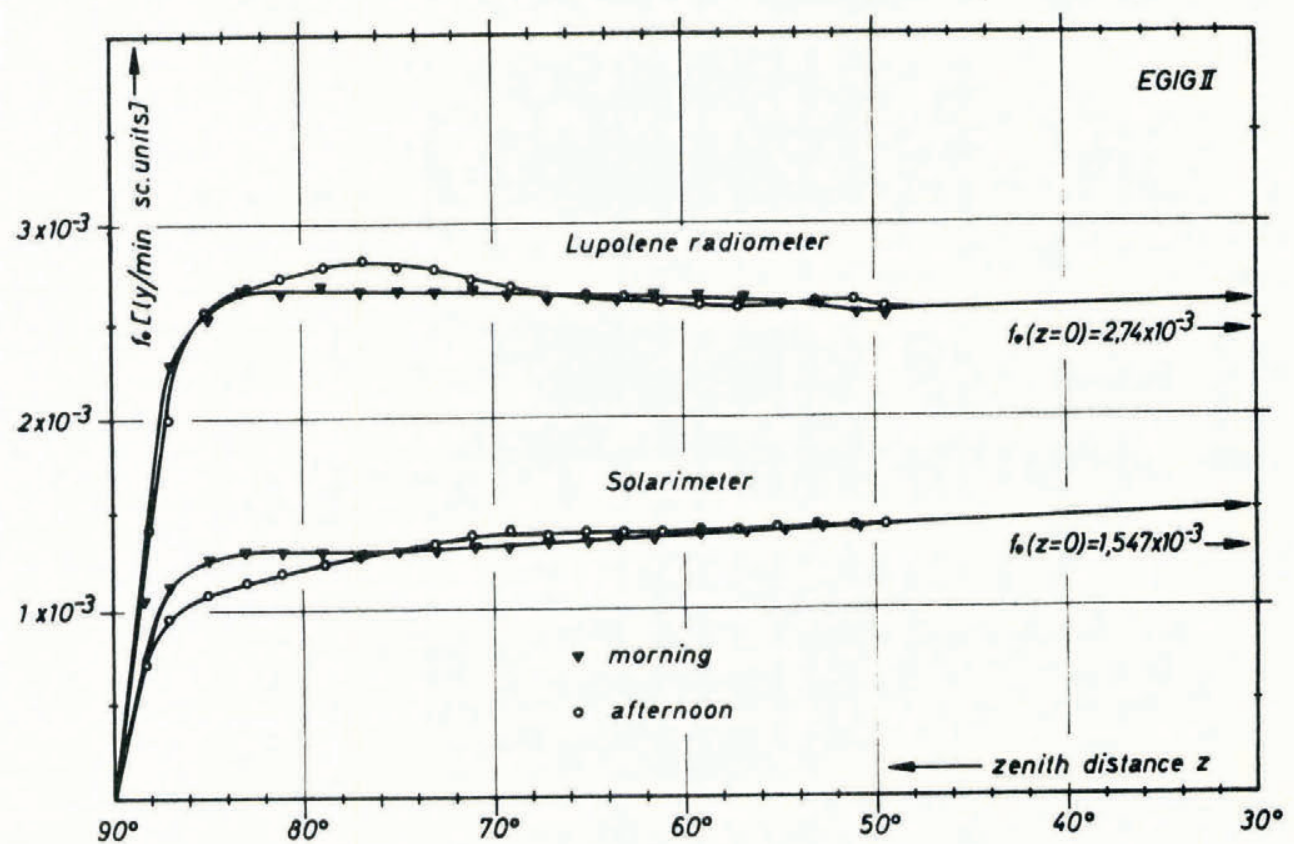

Fig. II. The calibration factors of the solarimeter and of the Lupolene instrument (Schulze) as dependent on zenith distance. 
where $f(h)$ represents the dependence of the calibration factor on the solar elevation $h$, averaged over values measured in the morning and in the afternoon.

For cloudless days, the evaluation was made by using the calibration factor as dependent on solar elevation. The share of sky radiation on cloudless days known from calibration measurements was evaluated with an adequate calibration factor $f_{\mathrm{d}}$, which was calculated according to the formula given by Liljequist (1956):

$$
\frac{\mathrm{I}}{f_{\mathrm{d}}}=\int_{0}^{\pi / 2} \frac{\cos h}{f(h)} \mathrm{d} h .
$$

Graphs for the evaluation of the formulae are shown in Figure 12. Days with a cloudiness of more than o/ 10 were treated with a calibration factor for isotropic radiation, as there exist no continuous records of diffuse sky radiation. The influence of the instrument holder on the albedo was accounted for by relative measurements with a portable solarimeter.

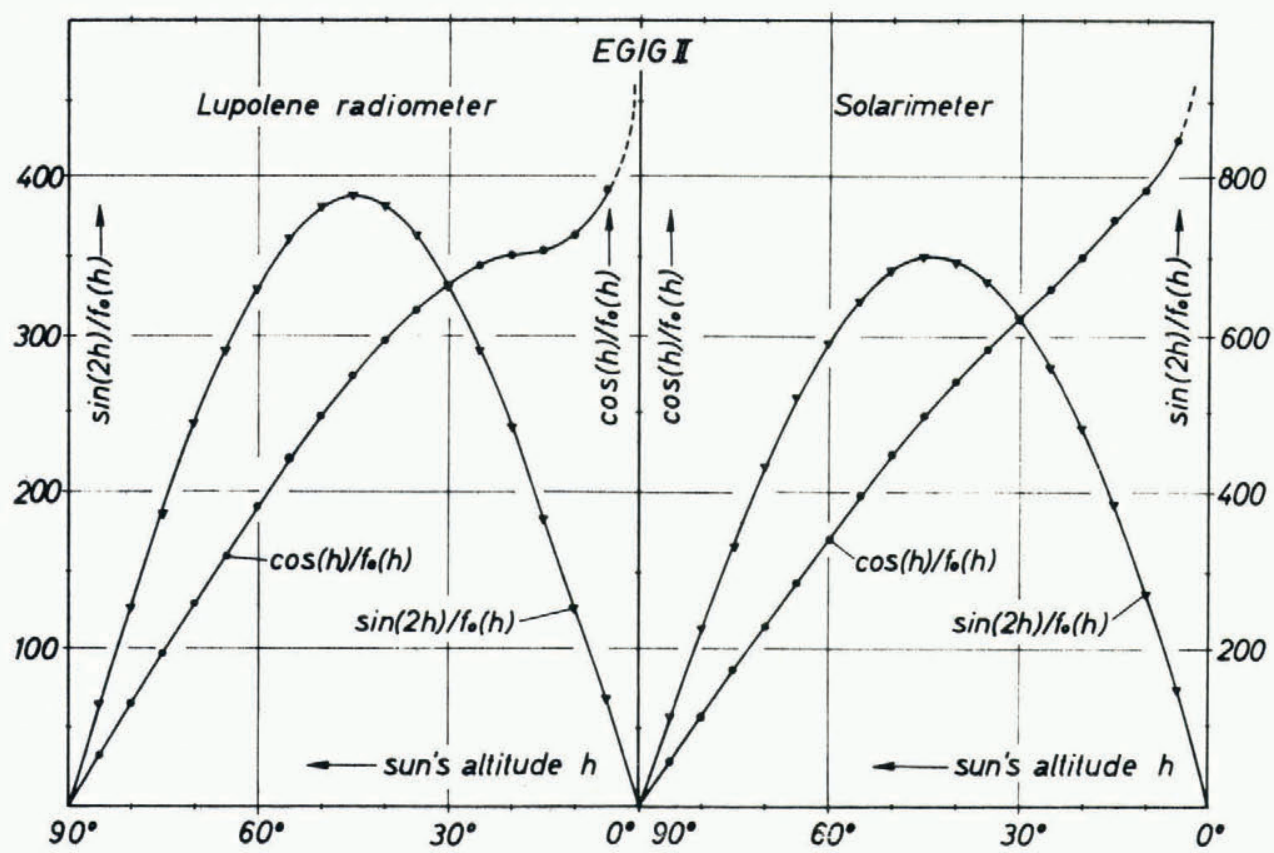

Fig. 12. Evaluation curves for calculating the calibration factor for diffuse isotropic radiation and for diffuse sky radiation with a clear sky.

\section{Acknowledgements}

The Fonds zur Förderung der wissenschaftlichen Forschung is thanked for supporting the evaluations. I also want to thank Mr G. Markl for assisting in the field work and Mr P. Quehenberger and Mrs J. Conen for helping with the evaluation.

MS. received I6 July 1973 


\section{REFERENCES}

Ambach, W. 1963. Untersuchungen zum Energieumsatz in der Ablationszone des grönländischen Inlandeises (Camp IV-EGIG, $69^{\circ} 40^{\prime}$ o5" N, $49^{\circ} 37^{\prime} 5^{\prime \prime} \mathrm{W}$ ). Meddelelser om Gronland, Bd. I 74, Nr. 4.

Ambach, W., and others. I963. Ưber die Eichung des Strahlungsbilanzmessers nach R. Schulze (Lupolengerät), von W. Ambach, E. Beschorner und H. [C.] Hoinkes. Archiv für Meteorologie, Geophysik und Bioklimatologie, Ser. B, Bd. 13 , Ht. 1, p. $76-95$.

Hoinkes, H. C. [' 1964 .] Glacial meteorology. (In Odishaw, H., ed. Research in geophysics. Vol. 2. Solid earth and interface phenomena. Cambridge, Mass., Massachusetts Institute of Technology Press, p. 391-424.)

Hoinkes, H. C. 1970. Radiation budget at Little America V, 1957. [Union Géodésique et Géophysique Internationale. Association Internationale d'Hydrologie Scientifique.] [International Council of Scientific Unions. Scientific Committee on Antarctic Research. International Association of Scientific Hydrology. Commission of Snow and Ice.] International Symposium on Antarctic Glaciological Exploration (ISAGE), Hanover, New Hampshire, U.S.A., 3-7 September 1968, p. $263-84$.

Holmgren, B. I971. Climate and energy exchange on a sub-polar ice cap in summer. Arctic Institute of North America Devon Island Expedition $1961-1963$. Part E. Radiation climate. Meddelanden fran Uppsala Universitets Meteorologiska Institution, Nr. 111 .

Liljequist, G. H. 1956. Energy exchange of an Antarctic snowfield. Short-wave radiation (Maudheim, $71^{\circ} 03^{\prime} \mathrm{S}$. , $10^{\circ} 6^{\prime}$ W.). Norwegian-British-Swedish Antarctic Expedition, 1949-52. Scientific Results, Vol. 2, Part 1A.

Sauberer, F., and Dirmhirn, I. 1952. Der Strahlungshaushalt horizontaler Gletscherflächen auf dem hohen Sonnblick. Geografiska Annaler, Årg. 34, Ht. 3-4, p. 26r-9o. 